\title{
Dynamic heterogeneity: a framework to promote ecological integration and hypothesis generation in urban systems
}

\author{
S. T. A. Pickett ${ }^{1}$ - M. L. Cadenasso ${ }^{2}$ - E. J. Rosi-Marshall ${ }^{1}$ - K. T. Belt ${ }^{3}$. \\ P. M. Groffman ${ }^{4}$ - J. M. Grove ${ }^{3}$ - E. G. Irwin ${ }^{5}$ - S. S. Kaushal ${ }^{6}$ - S. L. LaDeau ${ }^{1}$ • \\ C. H. Nilon ${ }^{7}$ - C. M. Swan ${ }^{8}$ - P. S. Warren ${ }^{9}$
}

Published online: 30 June 2016

(C) The Author(s) 2016. This article is published with open access at Springerlink.com

\begin{abstract}
Urban areas are understood to be extraordinarily spatially heterogeneous. Spatial heterogeneity, and its causes, consequences, and changes, are central to ecological science. The social sciences and urban design and planning professions also include spatial heterogeneity as a key concern. However, urban ecology, as a pursuit that integrates across these disciplines, lacks a theoretical framework that synthesizes the diverse and important aspects of heterogeneity. This paper presents the concept of dynamic heterogeneity as a tool to explore how social and ecological heterogeneities interact and how they together act as both an outcome of past interactions and
\end{abstract}

S. T. A. Pickett

picketts@ caryinstitute.org

1 Cary Institute of Ecosystem Studies, Box AB, Millbrook, NY 12545, USA

2 Department of Plant Sciences, University of California Davis, Davis, CA 95616, USA

3 USDA Forest Service, Baltimore Field Station, University of Maryland, Baltimore County, Baltimore, MD 21227, USA

4 Advanced Science Research Center and Brooklyn College Department of Earth and Environmental Sciences, City University of New York, 85 St. Nicholas Terrace, New York, NY 10031, USA

5 Agricultural, Environmental and Development Economics, The Ohio State University, Columbus, OH 43210, USA

6 College Park, University of Maryland, College Park, MD 20740, USA

7 School of Natural Resources Fisheries and Wildlife, University of Missouri-Columbia, Columbia, MO 65211, USA

8 Department of Geography \& Environmental Systems, University of Maryland, Baltimore County, Baltimore, MD 21250, USA

9 Department of Environmental Conservation, University of Massachusetts - Amherst, Amherst, MA 01003, USA a driver future heterogeneity and system functions. To accomplish this goal, we relate heterogeneity to the fundamental concept of the human ecosystem. The human ecosystem concept identifies key processes that require operationalized models of dynamic heterogeneity in three process realms: the flow of materials, the assembly of urban ecosystem biota, and the locational choices humans make concerning land. We exemplify a specific dynamic model of heterogeneity in each of these realms, and indicate a range of complementary statistical approaches to integrate the drivers and outcomes of dynamic heterogeneity across the three realms. We synthesize a hierarchical framework for a theory of dynamic urban heterogeneity, noting its complementarity to other major urban theories and general model approaches. We hypothesize that human actions and structures amplify the dynamics of heterogeneity in urban systems.

Keywords Community assembly · Interdisciplinary · Locational choice $\cdot$ Spatial heterogeneity $\cdot$ Theory $\cdot$ Urban ecology $\cdot$ Ecosystem $\cdot$ Watershed

\section{Introduction}

There are many ways to conceive of cities and urban ecosystems (Marcotullio and Solecki 2013). An important one is as spatially heterogeneous and temporally dynamic mosaics (Pickett et al. 1997; Dow 2000; Pickett and Cadenasso 2008; McGrath and Shane 2012; Qureshi et al. 2014; Grove et al. 2015). Both pattern and process in such mosaics are of interest (Liu et al. 2007; Stevenson 2011), as emphasized by the term dynamic heterogeneity. The biophysical and social heterogeneity of urban systems can take many forms. From a biological ecosystem perspective, heterogeneity can appear in cities as the differential distribution of vegetation structure, as hotspots and dead zones of nutrient and organic matter 
processing, as patches of high versus low soil organic matter, or as the distribution of leaf litter and coarse woody debris in streams and drainage infrastructure, for example. Heterogeneity in the physical environment appears in such conditions as cooler and warmer zones of air and surface temperatures, or as locations of high atmospheric advection and contamination. In the biota, heterogeneity exists as different levels of species richness, as differential functions of introduced species, and as sources or sinks of disease organisms and their vectors, for example. Although this list of examples is long, it does not exhaust the kinds of bioecological heterogeneity that can exist in urban systems. Such heterogeneity in the biota and the physical environment is fundamental to general ecological theory (Scheiner and Willig 2011). In fact, five of the eight fundamental principles of ecology articulated by Scheiner and Willig (2011) specifically mention heterogeneity or centrally involve heterogeneity of pattern and process.

The heterogeneity of urban areas is also of interest from the perspectives of social sciences, urban design and planning, and policy and management (Dow 2000; Forman 2008; McGrath and Shane 2012). Social-economic heterogeneity is expressed in such things as zoning regulations, neighborhood identities, housing prices, patterns of investment in green versus grey infrastructure, and in tourist guide books. It is embedded in warnings about where to go and where to avoid, and where to seek the various amenities that people desire in urban systems. Importantly, we do not endorse "spatial determinism," in which social outcomes are explained solely by place, as exemplified by the classic Chicago School (Grove et al. 2015). Rather, we acknowledge that social and environmental relationships and the feedback between them are differentially distributed in space. Indeed, "space" in urban systems is clearly as much a social product as it is a locational description (Thierstein and Förster 2008).

There are various principles that employ urban heterogeneity in theory and in practice (Muth 1969; Zipperer et al. 2000; Band et al. 2005; Shane 2005; Jenerette et al. 2006; Pickett and Cadenasso 2008; Irwin 2010; Roy Chowdhury et al. 2011; Swan et al. 2011; Cadenasso 2013). However, in our pursuit of integrative tools for social-ecological, long-term research, we have been hampered by the lack of a clear theoretical framework of dynamic heterogeneity that can facilitate communication across disciplines and can encourage melding of social and ecological perspectives and approaches. Therefore, in this paper we articulate a theoretical framework of urban ecology that addresses dynamic heterogeneity. Our view of urban ecology implies an integration with social sciences, and our view of heterogeneity encompasses both space and time, patterns and processes.

Other inclusive theories of urban systems exist, though none has been embraced as predominant or comprehensive of all factors of interest (Box 1; Batty 2013; Brenner 2014b; McHale et al. 2015). We do not propose heterogeneity theory as a replacement for those theories. All can contribute to a complete understanding of urban systems. However, those additional theories are beyond the scope of this paper.

Box 1: Other inclusive urban theories. The urban phenomena to be explained are many and diverse. The list is not exhaustive.

\footnotetext{
- The historical origin of cities some 5000 years ago in the Middle East (Reader 2004; Forman 2008).

- Contrasts in form or metabolism of urban systems compared to other ecosystems (Olson 1982; Gandy 2004; Heynen et al. 2006).

- Changing characteristics of cities with increasing size (Zipperer et al. 2000; Forman 2008; Bettencourt and West 2010).

- Political ecology (Bryant 1992; Robbins 2004).

- The role of cities and urban systems in an intensifying global network (Zipperer et al. 2000; Seto et al. 2012; Boone et al. 2014).

- Local-regional urban gradients and global change (Grimm et al. 2008).

- The continuum of urbanity (Boone et al. 2014).

- Urban economic models (Mills 1967; Arnott and Lewis 1979; Capozza and Helsley 1989).
}

\section{Plan of this paper}

This paper develops the concept of dynamic heterogeneity using the following scheme. First, we acknowledge that concern with heterogeneity in the urban realm is relevant because of the growing importance of city, suburban, and exurban (CSE) systems, along with their regional and global connections (Boone et al. 2014; Brenner 2014a). We then focus on the key insight that dynamic heterogeneity is important both as a driver and an outcome of biophysical and social urban processes. Heterogeneity in one feature of a CSE can act as a driver by interacting with temporal changes, pulsed events, or other patterns of heterogeneity to generate new spatial templates of heterogeneity - that is, heterogeneity as outcome. As driver and outcome, dynamic heterogeneity mediates between the social and the biological in CSE systems. We then apply the concept of dynamic heterogeneity to urban systems and present a hierarchical structure of a general theory of urban heterogeneity. The hierarchy uses an inclusive theory that has a general principle - that urban systems are organized as spatially differentiated, functionally significant mosaics. This general theory encompasses more focused, middle-level theories that are intended to represent the full range of processes and patterns that contribute to the higher level, general theory. Middle level theories themselves encompass a variety of more specific and mechanistic models of urban pattern and process that can be tested or applied in specific situations. The articulation of expectations and hypotheses representing middlelevel theories and the integration among middle- and lowerlevel theories is an important frontier for urban ecology. 


\section{Defining dynamic urban heterogeneity}

The spatial relevance of dynamic heterogeneity is broad because urban systems consist of CSEs and because they are parts of regionally and globally connected systems (Schmid 2014). Heterogeneity can appear at all spatial scales that occur within CSEs, as well as across urban agglomerations and megaregional networks (Harrison and Hoyler 2014). However, urban heterogeneity is not stationary in time (McGrath and Shane 2012). Rather, human and natural processes and the interaction between them are dynamic (Alberti 2008). Therefore, spatial heterogeneity is as much about time and processes as it is about spatial structure, a feature emphasized by the phrase "dynamic heterogeneity." This sketch of an inclusive theory of dynamic heterogeneity is part of a long and broad tradition concerning the spatial structure of urban systems (Burgess 1925; Gottdiener and Hutchison 2011). It reflects one of the classic definitions of urban systems as contrasted with socially more homogeneous villages (Wirth 1945). Urban heterogeneity has motivated those interested in immigration (Taubenbock et al. 2014), social justice (Bryant 1995), urban planning (Sukopp and Weiler 1988), political power (Raleigh 2014), lifestyle identity (Grove et al. 2003), and indeed, many other topics. The social production of space (Lefebvre 1991), the patchy reinvention of cities and their enclaves over time (Shane 2005; McGrath and Shane 2012), and the recognition of fine scale social dynamics (Jacobs 1961) are examples of concern with dynamic heterogeneity beyond ecology.

Ecology has likewise had an important research focus on the dynamics of spatial heterogeneity. Population ecology, where the evolutionary significance of spatial difference within populations is clear (Levins 1968), perhaps began modern ecology's concern with heterogeneity. This continued through spatialization of community ecology via dispersal and metacommunity concerns (Chesson and Chase 1986), and on to the invention of landscape ecology as a disciplinary home for studies of heterogeneity (Forman 1981). Similarly, ecosystem ecology has come to acknowledge that both the heterogeneity represented by species and by spatial patchiness are significant for ecosystem functioning (Jones and Lawton 1995; Leibold et al. 2004; Band et al. 2005; Pickett and Cadenasso 2013).

Heterogeneity is more than mere pattern. It is dynamic, and so can act as both a driver and outcome (Wiens 2000) of biophysical processes, social processes, and the intertwining of those social-biophysical processes. A given heterogeneous array is an outcome of prior states of heterogeneity, which is why we label the initial observation of dynamics as $t_{1}$. Changes in that initial state of heterogeneity result from the effect of processes both within and from outside that array. That outcome can act as a driver of future system states because it interacts with additional processes or events. This interaction of heterogeneity with processes and events at a given time sets up heterogeneity at subsequent times, which is what it means to act as both a driver and an outcome (Fig. 1a). Because heterogeneity can be both a driver and an outcome, it is a particularly important focus for theory in complex systems (Cadenasso et al. 2006; McGrath and Shane 2012; Batty 2013), such as urban areas. Indeed, patchy distributions of resources, organisms, and processes are an outcome and driver of ecological change in all ecosystems. However, the presence of humans as a fundamental component of urban ecosystems amplifies dynamic heterogeneity compared to less human-dominated systems. We therefore argue that "dynamic heterogeneity" is a strong conceptual framework for longterm research in urban ecosystems that 1) integrates across ecosystem components, 2) allows us to develop predictions and general ecological questions that link processes and observations across levels of organization and temporal and spatial scales, and 3) develops predictive models.

\section{An example of emerging dynamic heterogeneity}

Feedbacks between and among ecological processes flow through filters of spatial heterogeneity (Wiens 2000). These feedbacks also construct new patterns of heterogeneity that can affect subsequent interactions (Pickett et al. 2000). An example might be the existence of a spatially heterogeneous pattern of forest trees, including ash trees (Fraxinus spp.; Fig. 1b). As the introduced emerald ash borer (Agrilus planipennis) invades and kills ash trees in North American cities (Jones and McDermott 2015), a new pattern of heterogeneity is generated - the distribution of forest canopy gaps created by ash mortality. Of course the actual mortality of ash trees in time and space is conditioned by such things as preemptive cutting of ash trees by people, or by decisions to protect particularly valued ash trees through extraordinary actions (Fig. 1b; Jennings et al. 2015; Jones and McDermott 2015). Such conservative or adaptive actions are patchy and differentially distributed across a CSE mosaic. The subsequent heterogeneity of the forest is affected by natural succession or by compensatory planting of different tree species by forest managers. This emerging "ash spiral" of interacting heterogeneities with natural and socially driven events is now underway in many urban areas in the eastern U.S. Thus, the interactions between different elements of heterogeneity are key mechanisms of urban dynamics. Of course, urban dynamics are also affected by social and biophysical structures and fluxes from outside their boundaries, or which operate on very long time frames in which the urban system is embedded (Olson 1982; Seto et al. 2012).

\section{The human ecosystem: A foundation for dynamic heterogeneity}

The classical ecosystem concept focuses on two components - biota and physical environments - and their 

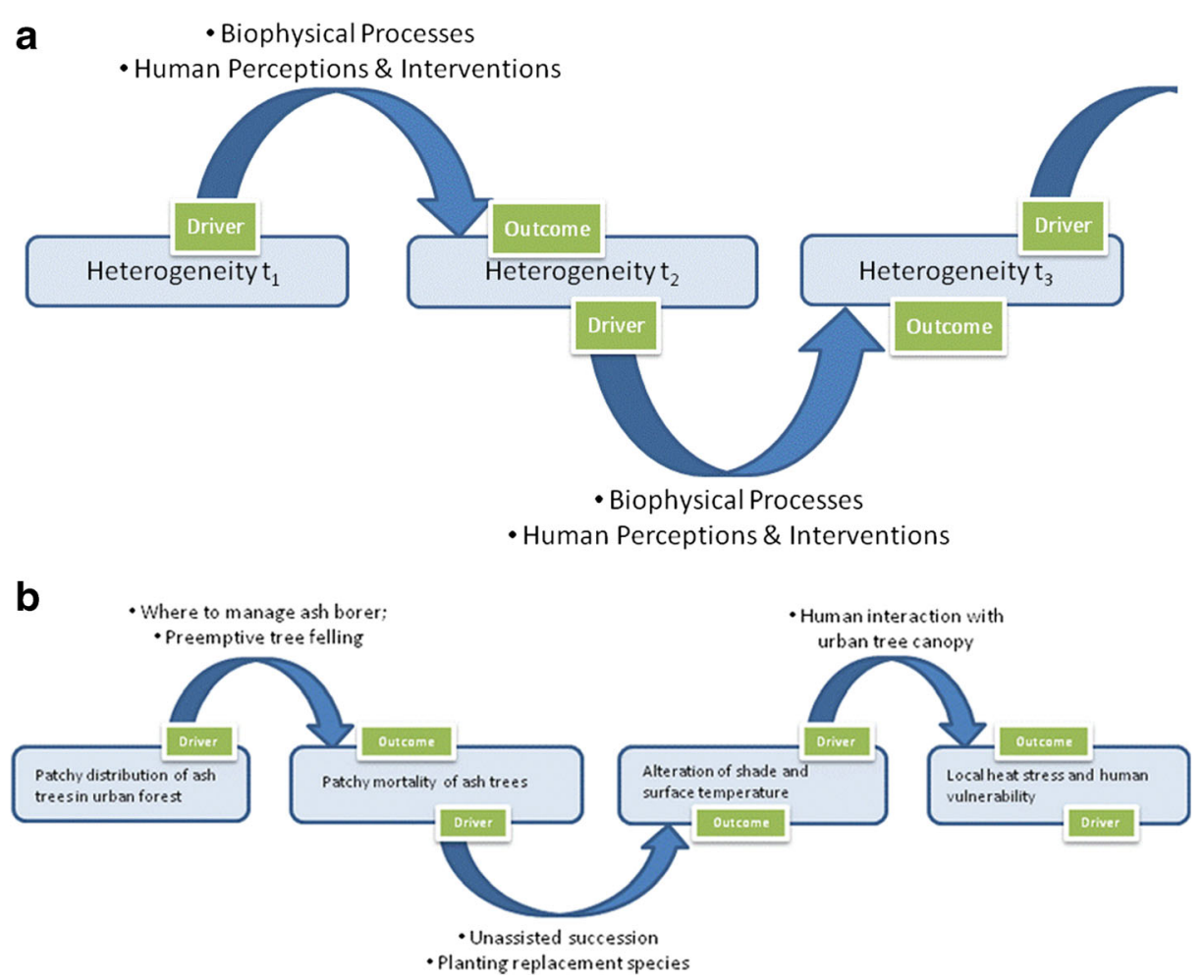

Fig. 1 Top: A general model template illustrating how dynamic spatial heterogeneity can be both a driver and an outcome, mediated by human perceptions and interventions. Although considering heterogeneity to be both driver and outcome may seem circular, this representation explains why that is not the case. Causation has a temporal dimension that separates the status as outcomes and driver, and acknowledges the role of both natural processes and human perceptions and consequent interventions between those two states. Bottom: A hypothetical scenario of dynamic heterogeneity acting as outcome and driver through an invasion process of the emerald ash borer and its cascading effects on the environemnt and human wellbeing. The right hand state of heterogeneity may act as a driver of other perceptions and interventions, but these are not shown for the sake of simplicity. Similarly, the processes and heterogeneities that establish heterogeneous ash distribution in an urban system are considered as starting boundary conditions $\left(\mathrm{T}_{0}\right)$ and are not modeled here interactions. In contrast, urban ecosystem models must add two additional kinds of components: a social complex, and a built complex, along with their interactions (Fig. 2; Cadenasso and Pickett 2008; Pickett and Grove 2009). All four of these components constitute a human ecosystem. Indeed, human ecosystems are biotic, physical, social, and built hybrids. Therefore to develop models of the human ecosystem all four components must be represented, as exemplified in the emerald ash borer spiral above (Fig. 1b).

All four components of human ecosystems (Fig. 2) can be heterogeneous. The role of heterogeneity in the functioning of biologically focused models of ecosystems is widely recognized (Hutchings et al. 2000; Lovett et al. 2005; Scheiner and Willig 2011). The human ecosystem concept suggests that heterogeneity also involves human decision-making processes and the buildings and infrastructure that result from these decisions (Fig. 2). The heterogeneous control of ecosystem structure and function (Shaver et al. 2007; Pickett and Cadenasso 2013) is an important general reserach question in ecology. To understand how heterogeneity influences the interaction among ecosystem components, we employ three broad process realms that structure ecosystems: 1) critical ecosystem fluxes, including their controls, pools, and transformations (Likens 1992); 2) the assembly of biological potential, that is, what organisms are present, their traits, community dynamics and spatial arrangement, and what influences their distribution (Chapin et al. 2011); and 3) the structures people build, the technologies they employ, their cultural contexts, and the decisions they make (Spirn 1984; Berry 1990; Smith and Stirling 2010). The flows of matter and energy, the assembly and biogeochemical potential of the biota, and human choices all interact reciprocally. The three process realms focus on entities and phenomena that hybridize the four components of the human ecosystem. All likewise interact with spatial heterogeneity through time so that pattern and processes are addressed. Material flows, biotic differentials, and human decisions are broad processes that all landscapes share (McDonnell and Pickett 1993). Therefore, these three realms are fundamental to understanding any ecosystem that includes people, their artifacts, or their effects. These three realms integrate across the components of the human ecosystem, and allow for examination of dynamic heterogeneity. While the process realms can be viewed through the familiar lens of pattern and process, the dynamic heterogeneity approach 
The Urban Ecosystem

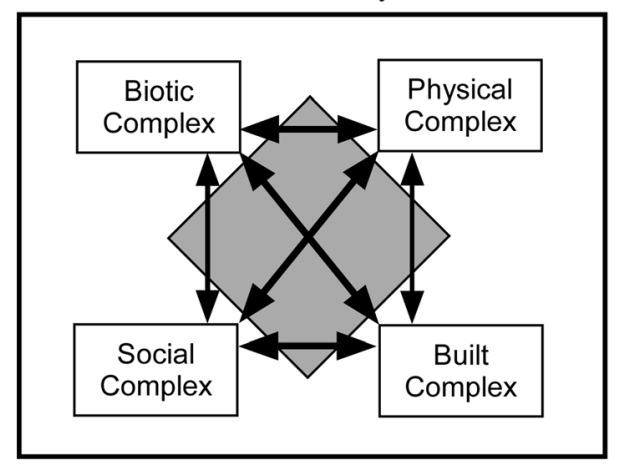

Fig. 2 Four components of urban ecosystems. Spatial heterogeneity is illustrated by the diamond intersecting with all the potential interactions among components. This diagram represents the fundamental concept employed in this paper, that spatial heterogeneity mediates the interactions among human ecosystem components, and that mediation will change through time as a result of those interactions. Note that the arrows illustrate potential interactions between components; research will determine which specific interactions exist and which ones are strongest or most dominant at particular spatial and temporal locations and scales

emphasizes that pattern is itself dynamic and is an active contributor to ecological change.

\section{A nested hierarchy of heterogeneity theory}

These three process realms are extraordinarily broad. In order to put them to work in generating clear explanations and hypotheses about dynamic heterogeneity in urban systems, more specific models and research approaches are required. Seeking such intermediates is akin to the use of "middle-level theories" as recommended in social science research (Merton 1968; Cadwallader 1988), and the use of hierarchical theories as employed in the natural sciences (Wu and Loucks 1995; Pickett et al. 2007; Scheiner and Willig 2011). The general theory for the entire discipline of ecology is supported by the key principles that organisms are variable, that environments are heterogeneous and historically contingent, and that organisms are mortal and are resource-limited. This broad and comprehensive theory is operationalized by more narrowly focused, middle-level theories. Such constituent theories are the familiar chapter headings of ecology textbooks, such as community assembly, ecosystem processes, life history evolution, negative and positive species interactions, environmental gradients, and so on (Scheiner and Willig 2011).

Such a theory for urban systems has yet to be sketched, but we suggest that a hierarchical approach made up of general theory, constituent or middle-level theories, and specific explanatory or predictive models is applicable to heterogeneity in urban systems (Fig. 3). The general theory states the overarcing scope of urban heterogeneity, that is, urban systems are heterogeneous, and that heterogeneity affects their ecological structure and function. We use the three process realms of flux of materials, assembly of biological potential, and human choice and the built environment as the middlelevel theories. Within each of these realms we present a mechanistic spiral of dynamic heterogeneity as an example of the specific testable or predictive model. As a caveat, in ecology the lower level specific models are themselves often called theory, but recognizing the need for complementarity of models and the fact that models usually contribute to a broader frameworks is important (Levins 1966).

Although there are many model types that might operationalize the three process realms, our choices are guided by 1) the ability to connect with broader disciplinary areas and 2) relevance to long-term urban processes. For the broad area of flow of materials, represented by water and contaminants, we employ an urban version of the watershed continuum concept (Groffman et al. 2004; Walsh et al. 2005; Kaushal and Belt 2012). For the broad area of differential spatial distribution and performance of organisms, we choose metacommunity theory as the representative translational concept (Swan et al. 2011). Finally, for the human decision making arena of theory, we apply locational choice theory that draws together concepts from economics, geography and urban planning (Irwin et al. 2009). We acknowledge that other modeling strategies are possible (e.g., Box 1); however, our roster is not determined by judgments against the ones not included but rather by its relevance to evolving urban CSE systems. We do not focus on such specific approaches as urban metabolism, the power law approaches to urban prediction, theories of the social production of space, or political ecology, for example. However, our explanations, specific models, and relevant data streams do address components of these other model approaches, and there is necessarily some mechanistic overlap with the set of theories outside our scope.

To illustrate the theoretical structure of each of these areas, we outline them using "if-then" statements that expose their conditional structure, which is an important form for biological theories (Pickett et al. 2007). If a stated condition or relationship holds, then a certain outcome is predicted. Such predictions can be tested in various ways: experiments, modeling, comparison, and long-term studies (Carpenter 1998). This structure is common to general theories in the physical and biological sciences, and it suggests the key hypotheses of those theories (Gould 1977; Pickett et al. 2007).

\section{The urban engineered watershed: A specific model for integrating flows}

The watershed concept integrates both stream and terrestrial components of landscapes connected by differential flows of water above and below ground (Bormann and Likens 1969; Fisher 1992; Fisher and Welter 2005). The complexity of watershed patterns and processes is illustrated by the river continuum concept (Vannote et al. 1980). Originally proposed to 
Fig. 3 A hierarchical structure of a general theory of urban heterogeneity, showing two basic principles about the occurrence and significance of dynamic heterogeneity and a domain statement identifying three realms of process that exist in urban ecosystems. Each of these process realms are middle-level theories, each of which must be operationalized through various specific models of heterogeneity as driver and outcome

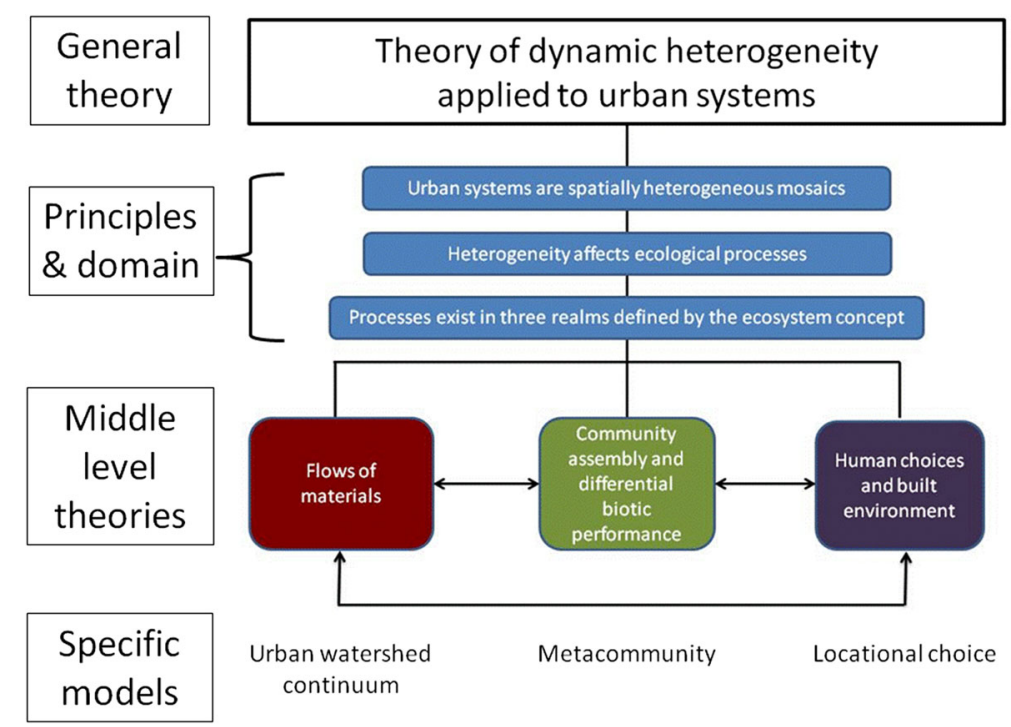

explain the shifts in the efficiency of energy use by aquatic organisms along the course of free-flowing rivers from headwaters to mouth, the river continuum concept links such drivers as channel width, energy sources from terrestrial versus aquatic production, and modes of acquisition of resources by the resident aquatic animals. Moving downstream along an ideal, forested river continuum, gradients of decreased inputs of allochthonous organic matter, increased access to sunlight as the stream widens, continual reduction of organic matter to smaller particles, and increased depth of the water column are expected (Fig. 4). If the availability of resources at the base of the food web shifts, then the modes of resource acquisition by aquatic animals will result in altered food web structure. The river continuum has been important in guiding specific models and tests in streams, some of which do not follow the ideal assumptions closely. This may be particularly the case for urban watersheds, due to heterogeneous anthropogenic conditions across space and time along urban engineered watersheds.

Urban engineered watersheds combine biological, physical, social, and built patterns and processes, making them an important tool for studying human ecosystems comprising cities, suburbs, and exurbs. In particular, applying the watershed concept to river networks that run through CSE systems requires its own set of specific assumptions and boundary conditions (Walsh et al. 2005). For example, the substantial re-plumbing of watersheds in urban ecosystems introduces new connections and blurs ecological boundaries between the terrestrial and riverine zones in the forms of pipes, drainage infrastructure, and altered hydrological flow paths (Fig. 4; Kaushal and Belt 2012). This leads to cascading impacts of heterogeneity on the water chemistry and ecosystem functions of urban watersheds across longitudinal, lateral, and vertical dimensions as well as through time (Kaushal and Belt 2012; Kaushal et al. 2014a): 1) Longitudinally, there can be significantly enhanced "hot spots" of gross primary production along the urban watershed continuum up to five times greater than forest streams due to light availability, which can be heterogeneous due to patchy riparian cover (Kaushal et al. 2014a). 2) Laterally, downcutting of urban streams due to the flashy delivery of rainwater from impervious surfaces typically disconnects the stream from its former floodplain. 3) Vertically, hydrological connections exist between ground water, drinking water supply pipes, storm drains, sanitary sewers, and surface streams. Longitudinal, lateral, and vertical patterns of disconnection and connection among pathways can shift biogeochemical functions from sinks to sources of contaminants, such as reactive nitrogen, which can impact eutrophication in streams and receiving waters (Groffman et al. 2002). Finally, 4) there is evolution in heterogeneity of ecosystem structure, function, and services of urban watersheds across the temporal dimension based on response to degradation, management, and restoration activities (Kaushal et al. 2014b).

Across both space and time, heterogeneity in the functioning of urban stream ecosystems is altered because some terrestrial-aquatic linkages are enhanced, while others are diminished. Hence, we use the new label urban watershed continuum to acknowledge the importance of heterogeneity across the space-time continuum. This label is intended to acknowledge the differences in terrestrial-aquatic linkages in urban watersheds compared to those for which the river continuum was initially conceptualized. The urban application goes beyond the focus on a single, longitudinal spatial dimension of natural streams, and also must include engineered hydrologic flowpaths, such as gutters, ditches, and pipes (Fig. 4b). The urban watershed continuum exemplifies the dynamic nature of heterogeneity as driver and outcome (Fig. 5).

The urban watershed continuum concept requires a set of detailed "if clauses" appropriate to urban systems. If re- 
Fig. 4 a The original stream continuum concept for non-urban streams, with stream order on the vertical axis, and stream width on the horizontal axis. b Built and modified features that must be added to the concept to apply to urban areas and which control the loading, distribution, and decomposition of organic matter. Sources A: Stream Corridor Restoration: Principles, Processes, and Practices, 10/98, by the Federal Interagency Stream Restoration Working Group (FISRWG); B Courtesy K.T. Belt

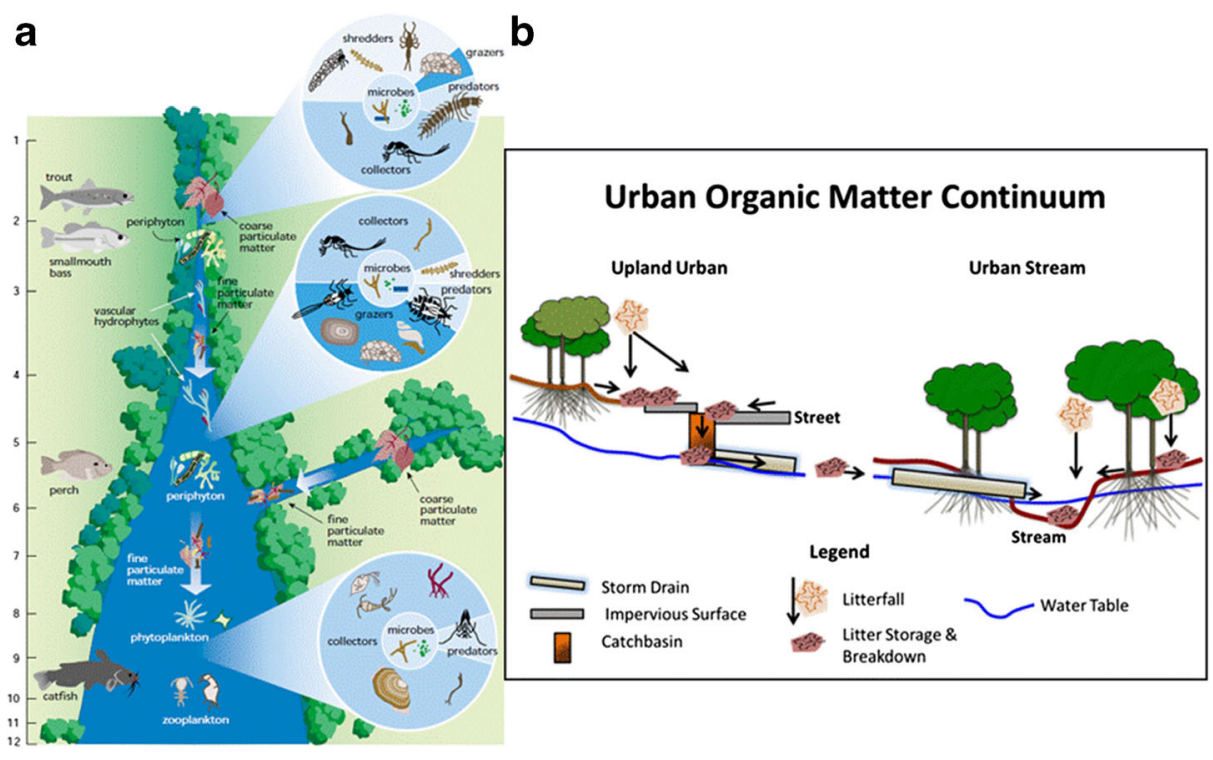

plumbing in CSE watersheds enhances the hydrologic connections between streams and the urbanized uplands, then we expect that organic inputs, temperatures, and nutrient pollution will be increased in all orders of streams affected. Temperature- and pollution-sensitive aquatic organisms will be disproportionally impacted. If streams of any size are disconnected from their former floodplains, then nitrogen removal functions of urban riparian zones will be impaired. Species composition will also shift with the drying out of stranded floodplains. We expect that the various interventions, connections, and effects in urban watersheds can all be spatially and dynamically heterogeneous.

\section{The metacommunity: A specific model for biotic assembly and differential performance}

The metacommunity concept focuses on the differential distribution of organisms across heterogeneous space, especially those in which patches are isolated from one another by inhospitable or suboptimal matrix (Leibold 2011; Alexander et al. 2012). Patch configuration can be crucial in urban metacommunity dynamics. For example, some analyses find that patch adjacencies are strongly associated with the diversity and abundance of bees (Hinners et al. 2012) and migratory birds (Carlson 2006). Because both aquatic and terrestrial habitats in urban areas are heterogeneous, we expect the metacommunity approach to apply to both those kinds of ecosystem patches. These additions to metacommunity theory, which account for human actions and decisions, are needed to apply metacommunity theory to urban situations (e.g., Swan et al. 2011).

The metacommunity approach makes predictions based on the following logic, in which several if statements identify the causal factors, and together those factors can result in several outcomes or then statements: If (1) sites are discrete, (2) sites are separated by contrasting and less- or un-suitable habitat, (3) species have differential abilities to disperse across a heterogeneous spatial mosaic, and (4) different species are differentially prone to extirpation in different habitat types, then (A) the local diversity of biotic communities will be determined

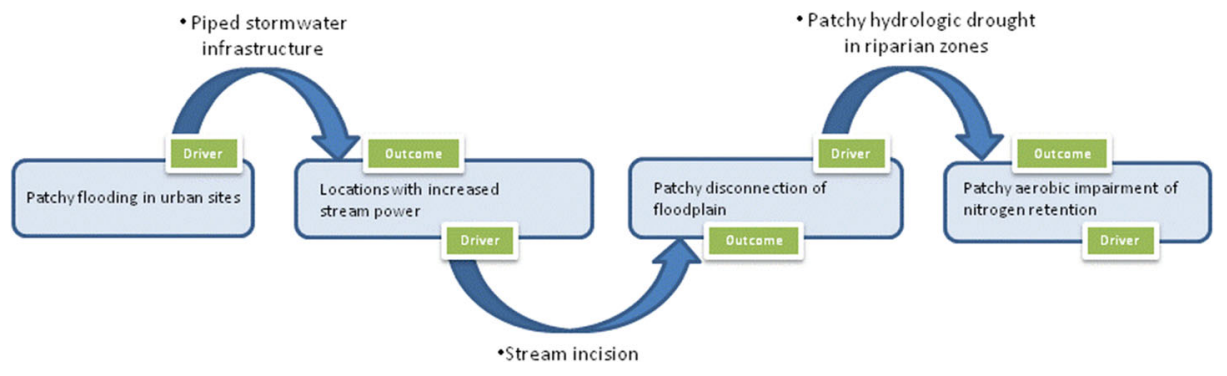

Fig. 5 A spiral of heterogeneity as driver and outcome of urban riparian disconnection and nitrogen dynamics. Patchiness in flooding has driven piped stormwater infrastructure in older city areas. This intervention in the context of high impervious surfaces, led to localized increased stream power. The driver of stream incision resulted, which as a result of the downcutting, stranded floodplains. Stranded floodplains drive heterogeneous hydrologic drought with consequent outcome of patchy reduction of the capacity of urban riparian zones to retain nitrate. Other perceptions and interventions occur as regulatory environment changes through time, and alternative stormwater management strategies are available. However we do not detail that history or alternatives in this model 
by their spatial relationship to other patches, (B) the nature of the intervening mosaic will affect community composition, and $(\mathrm{C})$ these factors mediate the development of biodiversity at multiple spatial scales. A layer of complexity is added by human actions requiring an if statement unique to CSE systems: If (5) the role of human-mediated dispersal of species, either as propagules or active adults, predominates then (D) human mediation can override the effects of unassisted dispersal and the unmodified rate of local extinctions of sessile organisms.

In urban ecosystems, community assembly is dominated by management, with the relative importance of exotic and native species, spontaneous versus planted species, and selective pressures associated with urban stressors, including environmental pollution, heat island effects, etc., varying across space. Further, urban biotic communities are highly dynamic over time as organisms interact and respond to changes in human activity and management as well as to changing biophysical constraints (Hepinstall et al. 2008; Shochat et al. 2010; Nilon 2011). Dynamic heterogeneity is an outcome and driver of biotic communities (Fig. 6). For example, we have observed patchiness in land use legacies, such that on vacant lots, the areas within the boundary of the demolished structures are differentially colonized or invaded by plant species and communities compared to the former yards (Johnson et al. 2015). These patterns of plant diversity then may influence human perceptions about vacant lots and alter the sustainability goals and management practices for these lots. This in turn influences intentional removal or planting strategies. The combination of land use legacies, plant invasion, human perception and management lead to heterogeneous distributions of plant species in the urban landscape (i.e. increased beta diversity, Fig. 6; Swan et al. 2011).

In other cases, where the assumptions of metacommunity theory do not apply, local conditions may better explain heterogeneity and suggest new model complexity. In such cases, other specific hypotheses may address the responses to land cover types present in a mosaic landscape, the relative roles of the regional versus local species pools, people's lifestyle contrasts that affect biotic diversity and composition, the resources available for maintenance of plants and animals in different locations, the differential vagility of various taxa, and so on (Matteson and Langellotto 2010; LaDeau et al. 2013; Beauchamp et al. 2015; Johnson et al. 2015; Swan et al. 2016). For example, 94 species of birds were observed at 132 bird sampling points in Baltimore during the breeding season. The BirdLife International Range Maps suggest that 161 bird species could live in Baltimore (Aronson et al. 2014). The difference indicates that heterogeneity in such features as land use and land cover act as filters for some species during the breeding season. In other cases, local conditions explain heterogeneity in bird and mobile insect species (Croci et al. 2008; Matteson and Langellotto 2010). Metacommunity theory provides a tool for diagnosing the mechanisms yielding these different associations between spatial heterogeneity and diversity and abundance of biota. Urban-specific if statements generate new models.

\section{Locational choice: A specific model for human decisions and the built environment}

Locational choice theory focuses on the differential distribution of households and firms (Weber 1929; Hoover 1948; Lösch 1954; Isard 1956; Tiebout 1956; Myrdal 1957; Alonso 1964; Christaller 1966; von Thünen 1966; Krugman 1991) based upon three fundamental economic forces that influence location: (1) natural advantages that attract households and firms; (2) economies of concentration that enhance the productive efficiency of firms that cluster; and (3) transportation and communication costs that spatially differentiate markets and their geographical extent (Edgar and Giarratani 1999). Key extensions of locational choice theory (Graves 1980; Haurin 1980; Roback 1982) have demonstrated the importance of amenities and disamenities to explain the locational choices of households and jobs. These include urban amenities such as culture (Glaeser et al. 2001; Florida 2005) and natural amenities such as climate (Cragg and Kahn 1997) and coastlines (Rappaport and Sachs 2003; Oliva 2006); and disamenities such as crime (Cullen and Levitt 1999).

Locational choice theory can make predictions based upon "if-then" statements: if (1) households make locational choices to improve their well-being, and (2) households are

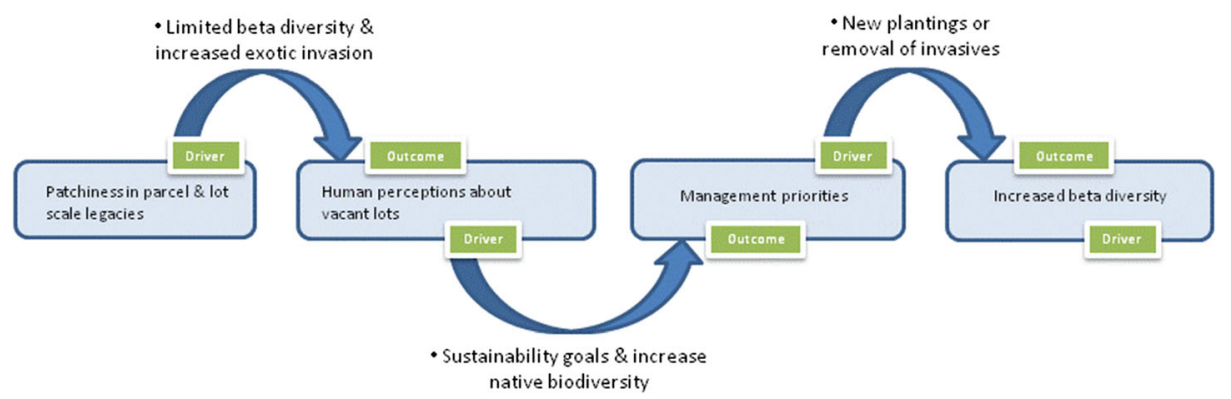

Fig. 6 A spiral of metacommunity dynamics as affected by environmental heterogeneity of unassisted community assembly, as well as by heterogeneity of facilitation by humans of local communities. The entire ecological template is spatially heterogeneous and affects the relationship of species composition in specific patches in relation to each other and to the regional species pool 
separated by locations providing greater or lesser well-being (i.e. locations are heterogeneous), then a household's location will reflect its optimal combination of preferences for amenities and disamenities for a given set of constraints, such as income, that limit that choice. A range of economic, social, and institutional drivers may influence locational choices (Alonso 1964; Muth 1969; Harr et al. 1975; Alperovich 1982; Logan and Molotch 1987; Mieszkowski and Mills 1993; Cho 2001; Bayoh et al. 2006).

How do the choices people make about where they live and how they use and manage their land reciprocally interact with dynamic heterogeneous ecological conditions? The decisions people make appear at multiple scales and can influence ecological features of an urban region, and these ecological conditions in turn feed back to influence households, neighborhoods, municipalities, and governance networks. Ecological conditions can be perceived as amenities or disamenities that influence locational, land use or land management choices. While some ecosystem structures and functions may influence individual locational and management choices directly, many other feedbacks involve higher levels such as governance networks, zoning, and regulations to protect habitats and ecosystem functions.

Research on the long-term dynamics of locational choice has included the role of residential segregation in the production of urban heterogeneity and patterns of environmental inequalities. Lord and Norquist (2010) documented procedural mechanisms and patterns of racial bias in zoning decisions in Baltimore since the 1930s, particularly the long-term legacies of "redlining" of African-American communities, limitating the avialability of mortgages there. Additional historical research on restrictive deed covenants and neighborhood improvement associations show that racial discrimination continued long after the redlining maps were in force (Boone 2013). Other environmental inequalities such as those associated with the uneven distribution of parks (Boone et al. 2009), current distributions of urban heat islands (Huang et al. 2011), tree canopy cover, and vacant lots (Grove et al. 2015) are closely aligned with neighborhoods that were redlined during the 1930s. We hypothesize that these long-term patterns create persistent legacies that constrain current and future locational and land choices in several ways. First, residents' long-term experience with disinvestment and absence of green amenities may influence their sense of place, and constrain their vision of a greener, more sustainable environment. Second, past experiences with disinvestment, failed government programs, and inability to maintain current green investments may cause residents to eschew new greening programs. Third, concerns over gentrification and displacement may lead residents to be reluctant to support greening and sustainability initiatives that may affect neighborhood desirability and property values and therefore may cause them to be displaced by gentrification. Further, certain "green investments" may in fact serve as disamenities in certain contexts in the absence of active stewardship and management. For instance, it has been found that in Baltimore that property values are negatively affected by proximity to parks when those parks are characterized by high crime, while in low crime areas the opposite is true (Troy and Grove 2008). While the procedural mechanisms for these racial biases have decreased over time (Lord and Norquist 2010), attempts to remedy these conditions are hindered by legacies of the city, making social ecological redevelopment, and the adoption of sustainability practices more difficult in neighborhoods of disinvestment (Fig. 7; Battaglia et al. 2014).

\section{Integrating the three middle level theories: Flow, biotic potential, and human choice}

The three realms and their middle-level theory should not be treated as disconnected models and empirical pursuits. As important as each of the three conceptual areas are in orienting long-term data collection and in motivating hypotheses, they are equally important as stimuli for integration. Urban ecology is continually challenged to integrate over spatial scales, over temporal scales, and across the many disciplines that are concerned with the structure, functioning, and shaping of urban systems (Pickett et al. 2001; Grimm and Redman 2004; Alberti 2008; Hahs et al. 2009). The three middle-level theories focusing on flux, biotic assembly and potential, and human choices, help integration by narrowing the universe over which integration must be accomplished. Integration among the middle-level theories is accomplished by specific models that identify types and magnitudes of connections. In essence, integration can focus on how each of the major process areas relates to the other two and what feedbacks exist among them. How does the nature of locational choices explain community assembly and biodiversity patterns in the metacommunity; how does it help us understand urban watershed structure? Likewise, how do watershed processes and patterns explain patterns in locational choices and metacommunity structure? Finally, how does the structure and change in the metacommunity mediate the structure and function of the watershed and people's locational choices? The feedbacks embedded in this set of questions are particularly important for ferreting out the integrative interactions that occur in the urban social-ecological system.

We emphasize three general protocols for facilitating quantitative synthesis that includes urban long-term data. These protocols are not mutually exclusive; each meets a specific analytical goal.

1. If a process is well-understood, then mechanistic or simulation models can be important tools for generating hypotheses about what types of environmental influences 


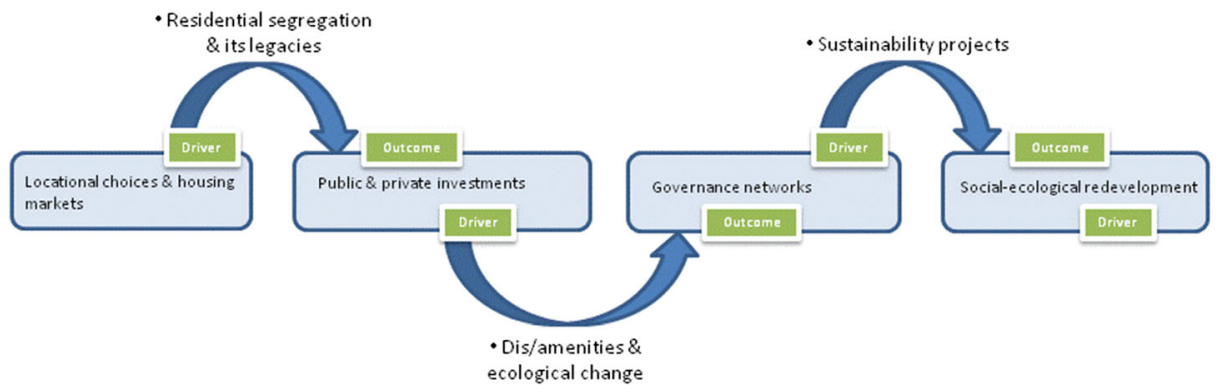

Fig. 7 A spiral of social-ecological interactions affected by legacies of racial segregation in housing markets. Differential investments in neighborhoods and resulting distributions of environmental amenities

drive deviations from predicted outcomes and for evaluating how processes will be affected by changes in common urban variables such as land cover, management, and climate.

2. When there is uncertainty about the relative importance of predictive variables or process structure, then it is important to let the data drive understanding through statistical models. In such cases, hierarchically structured statespace models can be employed. A hierarchical or multilevel model structure defines how information is shared across sampling units and processes, allowing researchers to accommodate important differences (e.g., among groups, individuals, or regions) while still allowing for shared characteristics (e.g., Clark and Bjornstad 2004; Clark et al. 2005). Bayesian or likelihood-based analysis (LaDeau and Clark 2006; Luo et al. 2011), or state-space formulations for understanding a process or state that is not directly observed can be used.

3. When the goal is to understand how ecological processes will be affected by some real or hypothetical scenario, e.g., change in land cover, management, climate, and and disamenities influence social-ecological redevelopment through targeted sustainability projects

uncertainty in process or data are a concern, then research can employ Bayesian Networks to evaluate likely outcomes (Fig. 8). Bayesian Network models are important tools in decision science and have gained attention as important tools for probabilistic evaluation of management outcomes in ecological systems (McCann et al. 2006; Leigh et al. 2011; Maxwell et al. 2015).

\section{Conclusion: Back to inclusive, general theory}

The theory of urban heterogeneity is a nested hierarchical conceptual structure that puts the following general principle into practice - urban systems are organized as spatially differentiated, functionally significant mosaics (Fig. 3). Specifically, it first assumes that urban systems are preeminently heterogeneous. Second, it assumes that there are different layers of heterogeneity, representing both biophysical and social features. Third, the layers of heterogeneity are assumed to interact at various scales. Fourth, the interactions of different layers of heterogeneity
Fig. 8 A representation of the variables that can be related and analyzed by the various statistical approaces focusing on networks of interaction. Scales of analysis are shown by the three grey boxes labeled growing season, watershed, and year

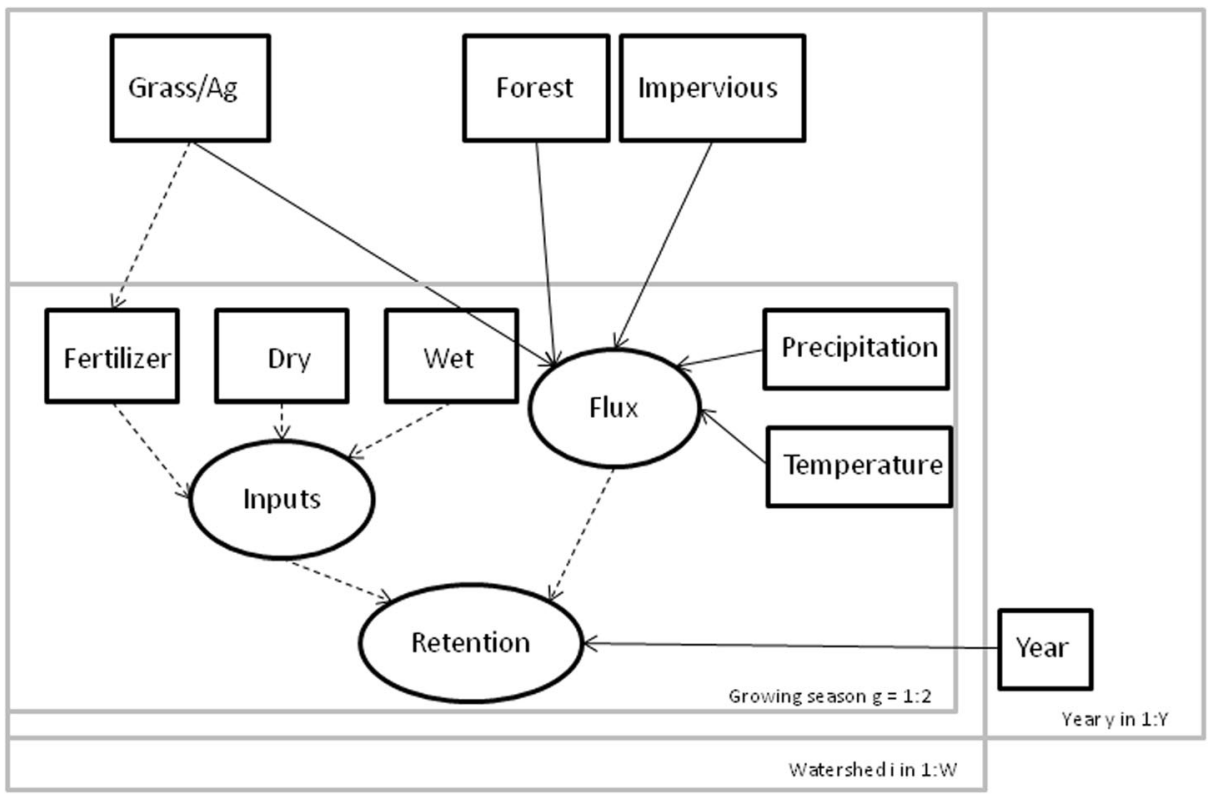


generate new heterogeneities. This leads to a fifth statement, the general prediction that heterogeneity can act as both driver and outcome in urban systems. Finally, this train of logic and empirical predictions is significant because heterogeneity is hypothesized to affect ecosystem functioning. This sixth proposition is consonant with a test of general theory of ecology with its core focus of the role of spatial and heterogeneity and its temporal changes. A novel hypothesis especially relevant to urban systems now emerges: dynamic heterogeneity is amplified by the intensity and speed of human-biophysical feedbacks in urban systems.

The general principle of the inclusive theory we have adopted can be tested, operationalized, and explained by three main sorts of process: the flow of materials, the differential distribution and performance of the biota that are key elements in ecosystem processes, and the choices that people, represented by individuals, households, organizations, and many other kinds of institutions, make about where to locate and what activities to conduct in specific places.

Each of these three constituent middle-level theories of urban heterogeneity is itself still a large topic. As in any theory, more specific models and research approaches are required to further translate the broad concepts and principles into operational models and specific hypotheses. We have explored a dynamic heterogeneity spiral as a tool to represent the interaction of different kinds of heterogeneity and urban processes and events. The spiral of dynamic heterogeneity can be considered a template to guide development of specific models of the structure, change, and importance of urban heterogeneity as driver and outcome. Our conceptual hierarchy is capped by an inclusive theory of urban spatial heterogeneity (Fig. 3). The theoretical framework has a second level that explores three broad subtheories, which are derived from the components of the human ecosystem. These subtheories supply mechanisms for the general theory, and they require still more detailed specific models and hypotheses to motivate data collection, empirical evaluations, and statistical tests.

Acknowledgments This research was supported by funding from the NSF Long-term Ecological Research (LTER) Program under Grant No. DEB-1027188 and the Urban Sustainability RCN Grant No. RCN 1140070.

Open Access This article is distributed under the terms of the Creative Commons Attribution 4.0 International License (http:// creativecommons.org/licenses/by/4.0/), which permits unrestricted use, distribution, and reproduction in any medium, provided you give appropriate credit to the original author(s) and the source, provide a link to the Creative Commons license, and indicate if changes were made.

\section{References}

Alberti M (2008) Advances in urban ecology: integrating humans and ecological processes in urban ecosystems. Springer, New York

Alexander HM, Foster BL, Ballantyne F, et al. (2012) Metapopulations and metacommunities: combining spatial and temporal perspectives in plant ecology. J Ecol 100:88-103. doi:10.1111/j.1365-2745.2011.01917.x
Alonso W (1964) Location and land use toward a general theory of land rent. Harvard University Press, Cambridge

Alperovich G (1982) Density gradients and the identification of the central business district. Urban Stud 19:313-320. doi:10.1080 /00420988220080541

Arnott RJ, Lewis F (1979) The transition of land to urban use. J Polit Econ 87:161-169

Aronson MFJ, La Sorte FA, Nilon CH, et al. (2014) A global analysis of the impacts of urbanization on bird and plant diversity reveals key anthropogenic drivers. Proc R Soc B-Biol Sci. doi:10.1098/rspb.2013.3330

Band L, Cadenasso M, Grimmond CS, et al. (2005) Heterogeneity in urban ecosystems: patterns and process. In: Turner M, Jones C, Weathers K (eds) Lovett G. Ecosystem Function in Heterogeneous Landscapes, Springer New York, pp. 257-278

Battaglia M, Buckley G, Galvin M, Grove M (2014) It's not easy going green: obstacles to tree-planting programs in East Baltimore.

Batty M (2013) The new science of cities. MIT Press, Cambridge

Bayoh I, Irwin EG, Haab T (2006) Determinants of residential location choice: how important are local public goods in attracting homeowners to central city locations? J Reg Sci 46:97-120

Beauchamp VB, Swan CM, Szlavecz K, Hu J (2015) Riparian community structure and soil properties of restored urban streams: urban stream restoration outcomes. Ecohydrology n/a-n/a. doi:10.1002/eco.1644

Berry BJL (1990) Urbanization. In: Turner II B, Clark WC, Kates RW, et al. (eds) The earth as transformed by human action: global and regional changes in the biosphere over the past 300 years. Cambridge University Press, New York, pp. 103-120

Bettencourt L, West G (2010) A unified theory of urban living. Nature 467:912-913

Boone CG (2013) Social dynamics and sustainable urban design. In: Pickett STA, Cadenasso ML, McGrath B (eds) Resilience in ecology and urban design: linking theory and practice for sustainable cities. Springer, New York, pp 47-61

Boone C, Cadenasso ML, Grove JM, et al (2009) Landscape, vegetation characteristics, and group identity in an urban and suburban watershed: why the 60s matter. Urban Ecosystems 13:255-271. doi:10.1007/s11252-009-0118-7

Boone CG, Redman CL, Blanco H, et al. (2014) Reconceptualizing land for sustainable urbanity. In: Seto KC, Reenberg A (eds) Rethinking urban land use in a global era. MIT Press, Cambridge, pp. 313-330

Bormann FH, Likens GE (1969) The watershed-ecosystem concept and studies of nutrient cycles. In: van Dyne GM (ed) The ecosystem concept in natural resource management. Academic Press, New York

Brenner N (2014a) Introduction: urban theory without an outside. In: Brenner N (ed) Implosions/explosions: towards a study of planetary urbanization. jovis Verlag, Berlin, pp. 14-30

Brenner N (2014b) Implosions/explosions: towards a study of planetary urbanization. jovis Verlag, Berlin

Bryant RL (1992) Political ecology. Polit Geogr 11:12-36

Bryant JP (ed) (1995) Environmental justice: issues, policies, and solutions. Island Press, Washington DC

Burgess EW (1925) The growth of the city: an introduction to a research project. In: The city. University of Chicago Press, Chicago, pp. 47-62

Cadenasso ML (2013) Designing ecological heterogeneity. In: Urban design ecologies: AD reader. John Wiley \& Sons, Hoboken, pp. 271-281

Cadenasso ML, Pickett STA (2008) Urban principles for ecological landscape design and management: scientific fundamentals. Cities Environ 1:Article 4.

Cadenasso ML, Pickett STA, Grove JM (2006) Dimensions of ecosystem complexity: heterogeneity, connectivity, and history. Ecol Complex 3:1-12. doi:10.1016/j.ecocom.2005.07.002

Cadwallader M (1988) Urban geography and social theory. Urban Geogr 9:227-251

Capozza D, Helsley R (1989) The fundamentals of land prices and urban growth. J Urban Econ 26:295-306 
Carlson CE (2006) The relationship between breeding bird community structure in urban forest patches and the human-mediated resources in the surrounding residential matrix. University of Georgia, $\mathrm{PhD}$

Carpenter SR (1998) The need for large-scale experiments to assess and predict the response of ecosystems to perturbation. In: Successes, limitations, and frontiers in ecosystem science. Springer, New York, pp. 287-312

Chapin FS, Power ME, Cole JJ (2011) Coupled biogeochemical cycles and earth stewardship. Front Ecol Environ 9:3-3. doi:10.1890/15409295-9.1.3

Chesson PL, Chase TJ (1986) Overview: nonequilibrium community theories: chance, variability, history, and coexistence. In: Community ecology. Harper and Row, New York, pp. 229-239

Cho C-J (2001) Amenities and urban residential structure: an amenityembedded model of residential choice. Pap Reg Sci 80:483-498

Christaller W (1966) Central places in southern Germany. Prentice-Hall, New York

Clark JS, Bjornstad CN (2004) Population time series: process variability, observation errors, missing values, lag, and hidden states. Ecology 85:3140-3150

Clark JS, Ferraz GA, Oguge N, et al. (2005) Hierarchical Bayes for structured, variable populations: from recapture data to life-history prediction. Ecology 86:2232-2244

Cragg M, Kahn M (1997) New estimates of climate demand: evidence from location choice. J Urban Econ 42:261-284

Croci S, Butet A, Clergeau P (2008) Does urbanization filter birds on the basis of their biological traits? Condor 110:223-240

Cullen JB, Levitt SD (1999) Crime, urban flight, and the consequences for cities. Rev Econ Stat 81:159-169. doi:10.1162/003465399558030

Dow K (2000) Social dimensions of gradients in urban ecosystems. Urban Ecosyst 4:255-275

Edgar HM, Giarratani F (1999) An introduction to regional economics. West Virginia University, West Virginia

Fisher SG (1992) Pattern, process and scale in freshwater systems: some unifying thoughts. In: Aquatic ecology. Oxford University Press, London, pp. 575-591

Fisher SG, Welter JR (2005) Flowpaths as integrators of heterogeneity in streams and landscapes. In: Lovett GM, Jones CG, Turner MG, Weathers KC (eds) Ecosystem function in heterogeneous landscapes. Springer, New York, pp. 311-328

Florida RL (2005) The flight of the creative class. Harper Business, New York

Forman RTT (1981) Interaction among landscape elements: a core of landscape ecology. In: Proceedings of the international congress of landscape ecology. Pudoc, Wageningen, pp. 35-48

Forman RTT (2008) Urban regions: ecology and planning beyond the city. Cambridge University Press, New York

Gandy M (2004) Rethinking urban metabolism: water, space, and the modern city. City 8:363-379

Glaeser EL, Kolko J, Saiz A (2001) Consumer city. J Econ Geogr 1:2750. doi:10.1093/jeg/1.1.27

Gottdiener M, Hutchison R (2011) The new urban sociology, 4th edn. Westview Press, Philadelphia

Gould SJ (1977) Ever since Darwin: reflections in natural history. Norton, New York

Graves PE (1980) Migration and climate. J Reg Sci 20:227-237

Grimm NB, Redman CL (2004) Approaches to the study of urban ecosystems: the case of Central Arizona-phoenix. Urban Ecosyst 7:199-213

Grimm NB, Faeth SH, Golubiewski NE, et al. (2008) Global change and the ecology of cities. Science 319:756-760. doi:10.1126/science.1150195

Groffman PM, Boulware NJ, Zipperer WC, et al. (2002) Soil nitrogen cycle processes in urban riparian zones. Environ Sci Technol 36: 4547-4552. doi:10.1021/es020649z

Groffman PM, Law NL, Belt KT, et al. (2004) Nitrogen fluxes and retention in urban watershed ecosystems. Ecosystems 7:393-403. doi:10.1007/s10021-003-0039-x
Grove JM, Hinson K, Northrop R (2003) A social ecology approach to understanding urban ecosystems and landscapes. In: Understanding urban ecosystems: a new frontier for science and education. Springer-Verlag, New York, pp. 167-186

Grove M, Cadenasso ML, Pickett STA, et al. (2015) The Baltimore school of urban ecology. Yale University Press, New Haven

Hahs A, McDonnell MJ, Breuste J (2009) A comparative ecology of cities and towns: synthesis of opportunities and limitations. In: McDonnell MJ, Hahs A, Breuste J (eds) Ecology of cities and towns: a comparative approach. Cambridge University Press, New York, pp. 574-596

Harr RD, Harper WC, Krygier JT (1975) Changes in storm hydrographs after road building and clear cutting in the Oregon coast range. Water Resour Res 11:436-444

Harrison J, Hoyler M (2014) Megaregions. Globalization's new urban form? Edward Elgar, London

Haurin DR (1980) The regional distribution of population, migration, and climate. Q J Econ 95:293-308

Hepinstall JA, Alberti M, Marzluff JM (2008) Predicting land cover change and avian community responses in rapidly urbanizing environments. Landsc Ecol 23:1257-1276. doi:10.1007/s10980-0089296-6

Heynen N, Kaika M, Swyngedouw E (eds) (2006) In the nature of cities: urban political ecology and the politics of urban metabolism. Routledge, New York

Hinners SJ, Kearns CA, Wessman CA (2012) Roles of scale, matrix, and native habitat in supporting a diverse suburban pollinator assemblage. Ecol Appl 22:1923-1935

Hoover EM (1948) The location of economic activity. McGraw Hill, New York

Huang GL, Zhou WQ, Cadenasso ML (2011) Is everyone hot in the city? Spatial pattern of land surface temperatures, land cover and neighborhood socioeconomic characteristics in Baltimore, MD. J Environ Manag 92:1753-1759. doi:10.1016/j.jenvman.2011.02.006

Hutchings M, John EA, Stewart AJA (eds) (2000) The ecological consequences of environmental heterogeneity. Cambridge University Press, New York

Irwin EG (2010) New directions for urban economic models of land use change: incorporating spatial dynamics and heterogeneity. J Reg Sci 50:65-91. doi:10.1111/j.1467-9787.2009.00655.x

Irwin EG, Jayaprakash C, Munroe DK (2009) Towards a comprehensive framework for modeling urban spatial dynamics. Landsc Ecol 24: 1223-1236. doi:10.1007/s10980-009-9353-9

Isard W (1956) Location and space-economy. John Wiley \& Sons, Hoboken

Jacobs J (1961) The death and life of great American cities. Random House, New York

Jenerette GD, Wu J, Grimm NB, Hope D (2006) Points, patches, and regions: scaling soil biogeochemical patterns in an urbanized arid ecosystem. Glob Change Biol 12:1532-1544. doi:10.1111/j.13652486.2006.01182.x

Jennings DE, Duan JJ, Shrewsbury PM (2015) Biotic mortality factors affecting emerald ash borer (Agrilus planipennis) are highly dependent on life stage and host tree crown condition. Bull Entomol Res 105:598-606. doi:10.1017/S0007485315000498

Johnson AL, Tauzer EC, Swan CM (2015) Human legacies differentially organize functional and phylogenetic diversity of urban herbaceous plant communities at multiple spatial scales. Appl Veg Sci 18:513527. doi:10.1111/avsc.12155

Jones CG, Lawton JH (eds) (1995) Linkng species and ecosystems. Chapman and Hall, New York

Jones BA, McDermott SM (2015) Linking environmental management to health outcomes: a case study of the emerald ash borer. Appl Econ Lett 22:1409-1414. doi:10.1080/13504851.2015.1034836 
Kaushal SS, Belt KT (2012) The urban watershed continuum: evolving spatial and temporal dimensions. Urban Ecosyst. doi:10.1007 /s11252-012-0226-7

Kaushal SS, Delaney-Newcomb K, Findlay SEG, et al. (2014a) Longitudinal patterns in carbon and nitrogen fluxes and stream metabolism along an urban watershed continuum. Biogeochemistry 121:23-44. doi:10.1007/s10533-014-9979-9

Kaushal SS, McDowell WH, Wollheim WM (2014b) Tracking evolution of urban biogeochemical cycles: past, present, and future. Biogeochemistry 121:1-21. doi:10.1007/s10533-014-0014-y

Krugman PR (1991) Geography and trade. MIT press, Cambridge

LaDeau SL, Clark JS (2006) Elevated CO2 and tree fecundity: the role of tree size, interannual variability, and population heterogeneity. Glob Change Biol 12:822-833. doi:10.1111/j.1365-2486.2006.01137.x

LaDeau SL, Leisnham PT, Biehler D, Bodner D (2013) Higher mosquito production in low-income neighborhoods of Baltimore and Washington, DC: understanding ecological drivers and mosquitoborne disease risk in temperate cities. Int J Environ Res Public Health 10:1505-1526. doi:10.3390/ijerph 10041505

Lefebvre H (1991) The production of space. Blackwell, Oxford

Leibold MA (2011) The metacommunity concept and its theoretical underpinnings. In: Scheiner SM, Willig MR (eds) The theory of ecology. University of Chicago Press, Chicago, pp. 163-183

Leibold MA, Holyoak M, Mouquet N, et al. (2004) The metacommunity concept: a framework for multi-scale community ecology. Ecol Lett 7:601-613. doi:10.1111/j.1461-0248.2004.00608.x

Leigh C, Stewart-Koster B, Sheldon F, Burford MA (2011) Understanding multiple ecological responses to anthropogenic disturbance: rivers and potential flow regime change. Ecol Appl 22: 250-263. doi:10.1890/11-0963.1

Levins R (1966) The strategy of model building in population biology. Am Sci 54:421-431

Levins R (1968) Evolution in changing environments. Princeton University Press, Princeton

Likens GE (1992) The ecosystem approach: its use and abuse. Ecology Institute, Oldendorf/Luhe

Liu J, Dietz T, Carpenter SR, et al. (2007) Complexity of coupled human and natural systems. Science 317:1513-1516. doi:10.1126/science.1144004

Logan JR, Molotch HL (1987) Urban fortunes: the political economy of place. University of California Press

Lord C, Norquist K (2010) Cities as emergent systems: race as a rule in organized complexity. Environ Law 40:551-596

Lösch A (1954) The economics of location: translated from the second rev. Yale University Press, New Haven, German ed. by William H. Woglom with the Assistance of Wolfgang F. Stolper

Lovett GM, Jones CG, Turner MG, Weathers KC (2005) Ecosystem function in heterogeneous landscapes. In: Lovett GM, Jones CG, Turner MG, Weathers KC (eds) Ecosystem function in heterogeneous landscapes. Springer, New York, pp. 1-4

Luo Y, Ogle K, Tucker C, et al. (2011) Ecological forecasting and data assimilation in a data-rich era. Ecol Appl 21:1429-1442

Marcotullio PJ, Solecki W (2013) What is a city? an essential definition for sustainability. In: Boone CG, Fragkias M (eds) Urbanization and sustainability: linking urban ecology, environmental justice, and environmental change. Springer, New York, pp 11-25

Matteson KC, Langellotto GA (2010) Determinates of inner city butterfly and bee species richness. Urban Ecosyst 13:333-347. doi:10.1007 /s11252-010-0122-y

Maxwell PS, Pitt KA, Olds AD, et al. (2015) Identifying habitats at risk: simple models can reveal complex ecosystem dynamics. Ecol Appl 25:573-587. doi:10.1890/14-0395. 1

McCann RK, Marcot BG, Ellis R (2006) Bayesian belief networks: applications in ecology and natural resource management. Can J For Res-Rev Can Rech For 36:3053-3062. doi:10.1139/X06-238

McDonnell MJ, Pickett STA (eds) (1993) Humans as components of ecosystems. Springer New York, New York, NY
McGrath B, Shane G (2012) Introduction: metropolis, megalopolis, and metacity. In: Crysler CG, Cairns S, Heynen H (eds) The SAGE handbook of architectural theory. SAGE, Washington, DC

McHale MR, Pickett STA, Barbosa O, et al. (2015) The new global urban realm: complex, connected, diffuse, and diverse social-ecological systems. Sustainability 7:5211-5240. doi:10.3390/su7055211

Merton RK (1968) Social theory and social structure. The Free PRess, New York

Mieszkowski P, Mills ES (1993) ThecCauses of metropolitan suburbanization. J Econ Perspect 7:135-147

Mills ES (1967) An aggregative model of resource allocation in a metropolitan area.

Muth RF (1969) Cities and housing: the spatial pattern of urban residential land use. University of Chicago Press, Chicago

Myrdal G (1957) Rich lands and poor: the road to world prosperity. Harper \& Row, New York

Nilon CH (2011) Urban biodiversity and the importance of management and conservation. Landsc Ecol Eng 7:45-52. doi:10.1007/s11355010-0146-8

Oliva S (2006) The effects of watershed development on housing prices: the case of eastern Baltimore. University of Maryland, MA

Olson S (1982) Urban metabolism and morphogenesis. Urban Geogr 3: 87-109

Pickett STA, Cadenasso ML (2008) Linking ecological and built components of urban mosaics: an open cycle of ecological design. J Ecol 96:8-12. doi:10.1111/j.1365-2745. 2007.01310.x

Pickett STA, Cadenasso ML (2013) Ecosystems in a heterogeneous world. In: Weathers KC, Strayer DL, Likens GE (eds) Fundamentals of ecosystem science. Academic Press, New York, pp. 191-213

Pickett STA, Grove JM (2009) Urban ecosystems: what would Tansley do? Urban Ecosyst 12:1-8

Pickett STA, Jr WRB, Dalton SE, et al. (1997) A conceptual framework for the study of human ecosystems in urban areas. Urban Ecosyst 1: 185-199. doi:10.1023/A:1018531712889

Pickett STA, Cadenasso ML, Jones CG (2000) Generation of heterogeneity by organisms: creation, maintenance, and transformation. In: Hutchings ML, John EA, Stewart AJA (eds) Ecological consequences of habitat heterogeneity. Blackwell, Malden, MA

Pickett STA, Cadenasso ML, Grove JM, et al. (2001) Urban ecological systems: linking terrestrial ecological, physical, and socioeconomic components of metropolitan areas. Annu Rev Ecol Syst 32:127-157

Pickett STA, Kolasa J, Jones CG (2007) Ecological understanding. Academic Press, San Diego

Qureshi S, Haase D, Coles R (2014) The theorized urban gradient (TUG) method-a conceptual framework for socio-ecological sampling in complex urban agglomerations. Ecol Indic 36:100-110. doi:10.1016/j.ecolind.2013.07.010

Raleigh C (2014) Migration, urbanization, and political power in subSaharan Africa. Ann Assoc Am Geogr 104:253-261. doi:10.1080 /00045608.2013.875802

Rappaport J, Sachs JD (2003) The United States as a coastal nation. J Econ Growth 8:5-46. doi:10.1023/A:1022870216673

Reader J (2004) Cities. Atlantic Monthly Press, New York

Roback J (1982) Wages, rents, and the quality of life. J Polit Econ 90: $1257-1278$

Robbins P (2004) Political ecology: a critical introduction. Blackwell, Malden, MA

Roy Chowdhury R, Larson K, Grove JM, et al (2011) A multi-scalar approach to theorizing socio-ecological dynamics of urban residential landscapes. Cities Environ 4:Article 6.

Scheiner SM, Willig MR (eds) (2011) The theory of ecology. University of Chicago Press, Chicago

Schmid C (2014) Networks, borders, differences: towards a theory of the urban. In: Brenner N (ed) Implosions/explosions: towards a study of planetary urbanization. jovis Verlag, Berlin, pp. 67-80 
Seto KC, Reenberg A, Boone CG, et al. (2012) Urban land teleconnections and sustainability. Proc Natl Acad Sci U S A 109: 7687-7692. doi:10.1073/pnas.1117622109

Shane DG (2005) Recombinant urbanism: conceptual modeling in architecture, urban design and city theory. John Wiley \& Sons, Hoboken NJ

Shaver GR, Street LE, Rastetter EB, et al. (2007) Functional convergence in regulation of net $\mathrm{CO} 2$ flux in heterogeneous tundra landscapes in Alaska and Sweden. J Ecol 95:802-817. doi:10.1111/j.13652745.2007.01259.x

Shochat E, Lerman SB, Anderies JM, et al. (2010) Invasion, competition, and biodiversity loss in urban ecosystems. Bioscience 60:199-208

Smith A, Stirling A (2010) The politics of social-ecological resilience and sustainable socio-technical transitions. Ecol Soc 15:11

Spirn AW (1984) The granite garden: urban nature and human design. Basic Books, New York

Stevenson RJ (2011) A revised framework for coupled human and natural systems, propagating thresholds, and managing environmental problems. Phys Chem Earth 36:342-351. doi:10.1016/j. pce.2010.05.001

Sukopp H, Weiler S (1988) Biotope mapping and nature conservation strategies in urban areas of the Federal-Republic-of-Germany. Landsc Urban Plan 15:39-58. doi:10.1016/0169-2046(88)90015-1

Swan CM, Pickett STA, Szlavecz K, et al. (2011) Biodiversity and community composition in urban ecosystems: coupled human, spatial, and metacommunity processes. In: Niemelä J (ed) Handbook of urban ecology. Oxford University Press, New York, pp. 179-186

Swan CM, Johnson AE, Nowak D (2016) Differential organization of phylogenetic, taxonomic and functional diversity in an urban woody plant metacommunity.

Taubenbock H, Wiesner M, Felbier A, et al. (2014) New dimensions of urban landscapes: the spatio-temporal evolution from a polynuclei area to a mega-region based on remote sensing data. Appl Geogr 47: 137-153. doi:10.1016/j.apgeog.2013.12.002

Thierstein A, Förster A (eds) (2008) The image and the region: making mega-city regions visible! Lars Müller. Baden, Switzerland

Tiebout CM (1956) A pure theory of local expenditures. J Polit Econ 64: 416-424

Troy AR, Grove JM (2008) Property values, parks, and crime: a hedonic analysis in Baltimore, MD. Landsc Urban Plan 87:233-245

Vannote R, Minshall G, Cummins K, et al. (1980) River continuum concept. Can J Fish Aquat Sci 37:130-137. doi:10.1139/f80-017

von Thünen JH (1966) Isolated state: an English edition of der isolierte Staat. Pergamon Press

Walsh CJ, Roy AH, Feminella JW, et al. (2005) The urban stream syndrome: current knowledge and the search for a cure. J North Am Benthol Soc 24:706-723. doi:10.1899/0887-3593(2005)024\[0706 :TUSSCK 1$] 2.0 . \mathrm{CO} ; 2$

Weber A (1929) Theory of the location of industries [translated by CJ Friedrich from Weber's 1909 book]. The University of Chicago Press, Chicago

Wiens J (2000) Ecological heterogeneity: an ontogeny of concepts and approaches. In: Hutchins MJ, Stewart AJA (eds) The ecological consequences of environmental heterogeneity. Blackwell, Malden, MA

Wirth L (1945) Human ecology. Am J Sociol 50:483-488

Wu JG, Loucks OL (1995) From balance of nature to hierarchical patch dynamics: a paradigm shift in ecology. Q Rev Biol 70:439-466. doi:10.1086/419172

Zipperer WC, Wu JG, Pouyat RV, Pickett STA (2000) The application of ecological principles to urban and urbanizing landscapes. Ecol Appl 10:685-688. doi:10.1890/1051-0761(2000)010[0685 :TAOEPT]2.0.CO;2 